Fleming, T.H., Williams, C.F., Bonaccorso, F.J. \& Herbst, L.H. 1985. Phenology, seed dispersal, and colonization in Muntingia calabura, a neotropical pioneer tree. Am. J. Bot. 72: 383-391.

Forshaw, J.M. 1989. Parrots of the World, 3rd (revised) ed. Willoughby: Lansdowne Editions.

Galetti, M. 1993. Diet of the Scaly-headed Parrot (Pionus maximiliani) in a semideciduous forest in southeastern Brazil. Biotropica 25: 419-425.

Galetti, M. \& Rodrigues, M. 1992. Comparative seed predation on pods by parrots in Brazil. Biotropica 24: 222-224.

Grant, B.R. \& Grant, P.R. 1981. Exploitation of Opuntia cactus by birds on the Galápagos. Oecologia 49: 179-187.

Grant, P.R. \& Grant, B.R. 1980. Annual variation in finch numbers, foraging and food supply on Isla Daphne Major, Galápagos. Oecologia 46: 55-62.

Janzen. D.H. 1981. Ficus ovalis seed predation by an Orangechinned Parakeet (Brotogeris jugularis) in Costa Rica. Auk 98: $841-844$.

Jordano, P. 1983. Fig-seed predation and dispersal by bìrds. Biotropica 15: 38-41.

Long, J.L. 1984. The diets of three species of parrots in the south of Western Australia. Aust. Wildl. Res. 11: 357-371.

Long. J.L. 1985. Damage to cultivated fruit by parrots in the south of Western Australia. Aust. Wildl. Res. 12: 75-80.

O'Donnell. C.F.J. \& Dilks. P. 1993. Habitat use in autumn by forest birds on south east island, Chatham Islands. Notornis 40: 247252.

Oren, D.C. \& Novaes, A.C. 1986. Observations on the Golden Parakeet Aratinga guarouba in northern Brazil. Biol. Conserv. 36: 329-337.

Price, T.D. 1987. Diet variation in a population of Darwin's finches. Ecology 68: 1015-1028.

Sazima, 1. 1989. Peach-fronted Parakeet feeding on winged termites. Wilson Bull. 101: 656-657.

Schluter, D. 1982a. Seed and patch selection by Galápagos ground finches: Relation to foraging efficiency and food supply. Ecology 63: 1106-1120.

Schluter, D. 1982b. Distributions of Galápagos ground finches along an altitudinal gradient: The importance of food supply. Ecology 63: 1504-1517.

Smith, G.T. \& Moore, L.A. 1991. Foods of corellas Cacatua pastinator in Western Australia. Emu 91: 87-92.

Smith, J.N.M., Grant, P.R., Grant. B.R., Abbot, I.J. \& Abbot, L.K. 1978. Seasonal variation in feeding habits of Darwin's ground finches. Ecology 59: 1137-1150.

Wiens, J.A. 1989. The Ecology of Bird Communities, Vol. 1. Cambridge: Cambridge University Press.

Submitted 29 December 1995: revision accepted 24 August 1996

\section{Cooperative breeding between males in the Greater Rhea Rhea americana}

Parent ratite birds caring for eggs and chicks (the male in all species, also the major female in the Ostrich Struthio camelus and posstbly the female of the pair in the Emu Dromiceius novae-hollandiae; Handford \& Mares 1985) do not seem to rely on assistance from conspecifics in their breeding duties, although there is the suggestion that minor Ostrich hens (possibly mothers of some of the young) could make some contribution to incubation and offspring care (Sauer \& Sauer 1966).

After joint nesting and laying by the females of the harem, only the adult male Greater Rhea Rhea americana carries out incubation and brooding, leading and protecting the chicks without help from the females, and no case of cooperative breeding has been observed either in the wild or in captivity (Hudson 1927, Brito 1949, Raikow 1969. Bruning 1974). However, the observation in Argentina of four cases ( $3 \%$ ) of double nesting (in which two males nested less than $1 \mathrm{~m}$ apart, stole eggs from each other and, after hatching, shared the care of the chicks) suggests that male-male cooperative breeding sometimes occurs in this species (Fernández \& Reboreda 1995).

In this paper, we report the occurrence of cooperative breeding between males of the Greater Rhea and provide the results of observations that may throw light on the significance of the phenomenon for this species.

\section{METHODS}

This paper is based on observations of Greater Rhea living and breeding in a farming area (1980 ha) with natural and cultivated meadows, crops (wheat, soya, oats and maize) and livestock (cattle and horses) in Rio Grande do Sul, Brazil $\left(52^{\circ} 22^{\prime} \mathrm{W}, 28^{\circ} 4^{\prime} \mathrm{N}\right)$, during the breeding seasons (August-February) of 1990-1992, when the number of rheas varied from about 90 to 140 . The whole study area was examined at least once a week, and the occurrence and composition (age and sex classes) of all groups encountered were recorded.

In the study area, mixed groups of Greater Rhea (comprising birds of both sexes and all ages) are found throughout the year. At the start of the breeding season, solitary adult males and several smaller groups emerge from the mixed groups. Males defend harems of two to nine females against other males. After nest building (by the adult male), copulation and egg laying, the females move on to another male's territory in a polyandrous fashion. The adult male incubates and takes care of the young without participation by the females (T.L. Codenotti. 1995, unpublished $\mathrm{PhD}$ thesis. University of Córdoba).

Male age classes were categorized as follows (based on our observations and on Bruning 1973): independent juveniles (from about 7 months to about 2 years old, oval body outline, visible cloaca), subadults (more than 2 years old, deep white thighs) and adults (great body size, very swollen neck and chest and contrasting plumage colour pattern). All adult males were recognized individually by differences in body size and features of plumage. No attempt was made to mark individuals.

Observations on 27 adult and 8 subadult males involved $212 \mathrm{~h}$ of focal 15-min observations. The types of behaviour recorded for the males were alert posture, expelling other males from the breeding area, feeding, harem defence, male-male fighting, locomotion (either walking or running), neck-shaking display (a pre-copulatory display), open-wings courtship display and territorial calling. The only behaviour recorded for females was approaching the males while in the harem (Raikow 1969. Codenotti et al. 1995). 
Table 1. Median (Md) and interquartile range (Q) rates (events per hour) of the activities of the helping subadult Greater Rhea males and their aided adult males and of unaided adult males, and results of comparisons ${ }^{\mathrm{a}}$

\begin{tabular}{|c|c|c|c|c|c|c|c|c|c|}
\hline \multirow[b]{3}{*}{ Activity } & \multirow{2}{*}{\multicolumn{2}{|c|}{$\begin{array}{l}\text { Helpers } \\
(n=8)\end{array}$}} & \multirow{2}{*}{\multicolumn{2}{|c|}{$\begin{array}{l}\text { Aided adults } \\
\quad(n=8)\end{array}$}} & \multirow{2}{*}{\multicolumn{2}{|c|}{$\begin{array}{l}\text { Unaided adults } \\
\quad(n=19)\end{array}$}} & \multicolumn{3}{|c|}{$P$} \\
\hline & & & & & & & \multirow{2}{*}{$\begin{array}{l}\text { Helpers } v \\
\text { aided }\end{array}$} & \multirow{2}{*}{$\begin{array}{l}\text { Helpers } v \\
\text { unaided }\end{array}$} & \multirow{2}{*}{$\begin{array}{l}\text { Aided } v \\
\text { unaided }\end{array}$} \\
\hline & $M d$ & $Q$ & Md & $Q$ & $M d$ & $Q$ & & & \\
\hline Alert & 2.63 & 1.85 & 0.26 & 1.10 & 3.70 & 3.60 & $<0.02$ & n.s. & $<0.03$ \\
\hline Expelling male & 0.60 & 0.68 & 1.33 & 2.08 & 0.50 & 0.60 & $<0.02$ & n.s. & $<0.02$ \\
\hline Feeding & 124 & 59.7 & 80.6 & 28.3 & 53.3 & 21.4 & $<0.03$ & $<0.05$ & n.s. \\
\hline Harem defence & 0.05 & 0.31 & 0.45 & 0.96 & 9.25 & 0.70 & $<0.02$ & $=0.05$ & n.s. \\
\hline Male-male fighting & 0.00 & 0.26 & 0.45 & 0.45 & 0.10 & 0.30 & n.s. & n.s. & n.s. \\
\hline Locomotion & 142 & 45.6 & 135 & 97.2 & 87.8 & 33.4 & n.s. & n.s. & n.s. \\
\hline Neck-shaking display & 0.20 & 0.26 & 0.60 & 0.38 & 0.40 & 0.40 & $<0.02$ & $<0.05$ & n.s. \\
\hline Open-wings display & 5.06 & 8.71 & 15.3 & 13.4 & 13.3 & 4.90 & $<0.02$ & n.s. & n.s. \\
\hline Territorial calling & 0.26 & 0.35 & 4.00 & 0.65 & 2.70 & 1.50 & $<0.02$ & $<0.04$ & n.s. \\
\hline
\end{tabular}

${ }^{a}$ Wilcoxon test for helpers $v$ aided and Mann-Whitney test for aided $v$ unaided.

\section{RESULTS}

Out of the 35 harems observed during the 3 years, eight (23\%) included both a dominant adult male and a subadult male from the first formation of the harem. Both males came from the same mixed pre-breeding group (one individual adult male defended such twomale harems in both 1990 and 1992). One of these groups also involved a juvenile male which followed the group at a distance and even remained near the adult male during the whole incubation period but was never attacked by him.

Focal 15-min samples of the behaviour of adult ( $36 \mathrm{~h}$ of observation) and subadult $(30 \mathrm{~h}$ ) males from these eight groups revealed significantly greater rates of harem defence, territorial calling, expelling of other males from the breeding area, neck-shaking display and open-wings display by the adult male. Subadult males showed greater rates of feeding and alert behaviour. No significant differences were found for locomotion and male-male fighting (Table 1). The adult and subadult males were approached by females on 656 and 48 occasions, respectively ( $P<0.0001$, binomial test).

When the frequencies of behaviour types of the adults with a "helper" were compared with those obtained for 19 harem-holding adults without a helper ( $146 \mathrm{~h}$ of observation), the former showed lower values for alert posture and higher values for expelling other males from the breeding area. The comparison between unaided adults and the helper subadults showed higher rates of harem defence, neck-shaking display and territorial calling and lower rates of feeding by the aduits (Table 1 ).

In the two-male breeding units, the adult male built the nest and the females laid their eggs in it, after which the subadult male incubated the eggs alone. defending the nest against any approaching females although not against the adult male, who never showed any sign of aggression towards the subadult. When the adult male went on to build a new nest, also within his breeding territory, the same group of females (according to observations of group size and recognition of individuals) laid eggs again and the adult male incubated the second set of eggs.

The number of females in the two-male breeding units decreased from the time of laying in the first nest (median $(M d)=7$, inter- quartile range $(Q)=3.5, n=8$ ) to the time they accompanied the adult male before laying in the second nest $(M d=4.5, Q=2.5, n$ $=8$ ), but the difference was not significant. The harem size of 19 single male groups ( $M d=7, Q=3, n=19$ ) was not significantly different from that of double-male harems before laying in the first nest but was significantly greater than that of the double males just before laying in the second nest $(P<0.02$, Mann-Whitney test).

Clutch size was known for only four of those eight two-male breeding units (Table 2). For the 19 recorded single males (clutch size: $M d=23, Q=7$ ), no significant correlation was found between the harem size and clutch size $\left(r_{s 19}=0.56\right.$, n.s.).

Clutch size in the nests attended by the 19 single males was significantly greater than that of the four recorded second nests ( $M d=10, Q=6, P<0.05$, Mann-Whitney test) and not signifcantly different from that of first nests $(M d=19, Q=11)$. The combined clutch size resulting from summing the eggs of first and second nests in the two-male breeding units $(M d=29, Q=15)$ was not significantly greater than that of single adults.

The hatching success of the recorded four cases of adults with a young male $(48 \%)$ was not significantly different from that of their helping subadults $(60 \%$; Table 2$)$, nor were the combined values of these pairs of males (54\%) different from that of the 17 monitored single males $(69 \%)$.

Although at least five of the subadult helpers (out of the eight observed in two-male breeding units) were seen leading broods of young, we were able to monitor only the four mentioned above (Table 2). The proportions of chicks from first and second nests that reached the stage of unstriped young ( 5 months old, at which time the brown stripes on the back have disappeared) were not significantly different. The success rate of broods led by single males was lower ( $22 \%$ of unstriped young out of 247 hatchlings in the 17 remaining recorded broods) than that of broods led by aided adults (75\%; $P<0.02$, Mann-Whitney test) and was not different from that of broods led by the helper subadults $(17 \%)$ or from the combined success rate of the four two-male breeding units (40\%).

The comparison of the proportions of unstriped young out of the initial number of eggs between helper (10\%), aided ( $36 \%$ ) and sin- 
Table 2. Breeding success of broods attended by the four recorded two-male breeding units of Greater Rheas, date of laying of first egg and distance between them.

\begin{tabular}{|c|c|c|c|c|c|c|c|}
\hline Breeding units & Harem size ${ }^{a}$ & Clutch size & $\begin{array}{l}\text { No. eggs } \\
\text { hatched }\end{array}$ & $\begin{array}{l}\text { No. unstriped } \\
\text { young }\end{array}$ & $\begin{array}{c}\text { Date of first } \\
\text { egg laying }\end{array}$ & $\begin{array}{l}\text { Time elapsed } \\
\text { (days) }^{\mathrm{b}}\end{array}$ & $\begin{array}{l}\text { Distance } \\
\text { between first } \\
\text { and second } \\
\text { nests } \\
\text { (m) }\end{array}$ \\
\hline 1. Subadult & 9 & 23 & 21 & 7 & 6 Nov 1990 & 25 & 840 \\
\hline Adult & 6 & 19 & 9 & 8 & 8 Dec 1990 & & \\
\hline 2. Subadult & 10 & 23 & 21 & 0 & 11 Oct 1992 & 28 & 270 \\
\hline Adult & 3 & 18 & 11 & 9 & 16 Nov 1992 & & \\
\hline 3. Subadult & 4 & 9 & 0 & - & 8 Nov 1992 & 24 & 330 \\
\hline Adult & 5 & 9 & 0 & - & 6 Dec 1992 & & \\
\hline 4. Subadult & 5 & 15 & 0 & - & 2 Jan 1992 & 18 & 300 \\
\hline Adult & 6 & 12 & 8 & 4 & 27 Jan 1992 & & \\
\hline
\end{tabular}

a Size before start of incubation.

b Time elapsed between end of egg laying in first nests and beginning in second nests.

gle $(15 \%)$ males did not show any significant difference, nor was there a significant result from the comparison of the total number of unstriped young (helpers and aided: Table 2; single: $M d=2, Q$ $=5, n=17$ ).

\section{DISCUSSION}

Cooperative breeding by Greater Rhea males in our study area was common, and subadult males accepted all the tasks of incubation and chick rearing (although apparently not protecting the eggs and chicks efficiently from predation).

Although the subadults in the two-male breeding units showed interest in the females of the harem, the activities of the harem and territory defence were mostly performed by the adult males. which, according to their rates of courtship display and the females' much greater interest in them, probably fathered all or most of the young.

The lack of any relationship between harem size and clutch size might result from only a core of the females in the harem contributing to the clutch of eggs. If that were so, adult males would have no reason to hold larger harems but should hold the same one during two laying episodes or even retain only those females contributing to the clutch.

Probably because of the lack of sufficient data on the breeding success of the two-male breeding units, no advantage (but the higher success from hatchlings to juveniles of helped $v$ unhelped adults) was demonstrated statistically, and we should consider the present results only as a starting point, suggesting that under certain conditions being helped by a subadult may be advantageous for adult Greater Rhea males.

Until we have more information about the kinship relations between the adults and the helping subadult males and the consequences of helping, and on the basis of the wide range of benefits obtained by subadult helpers in other bird species (Brown 1987, Skutch 1987. Stacey \& Koenig 1990), we can only speculate on what benefits helping may provide the subadult male Greater Rheas: (1) gaining direct reproductive success (if they father some of the young, as for beta male helpers in Dunnocks Prunella modularis; Davies 1985), (2) gaining indirect reproductive success (if, coming from the same mixed groups, the subadult male helpers were genetically related to the adults), (3) acquiring experience in reproduction (in sexual relations, territory defence, incubation and chick rearing) and (4) because these birds are long-lived and live in stable groups, obtaining a higher reproductive status if their helping behaviour and reproductive success were supervised and valued positively by the females.

The four cases of double nests incubated by two males less than $1 \mathrm{~m}$ apart, reported by Fernández and Reboreda (1995) in Argentina, apparently do not represent the same kind of phenomenon described in this paper. First, although not specifically stated, both males were apparently adults. Second, the number of eggs in the two nests combined was not different from that in single nests, the former probably resulted from only one laying episode by the females.

We thank J. A. Amat, E. Aguilera and T. Redondo for valuable suggestions on the manuscript. Funding was provided by SBPN and CNPq (Brazil) and DGICYT (PB92-0115, Spain).

Thais L. Codenotti' \& Fernando Alvarez' ' Universidade de Passo Fundo, Cx. p. 563, 99100-000 Passo Fundo/RS, Brazil; ${ }^{2}$ Estación Biológica de Doñana, C.S.I.C., Apartado Postal 1056, 41080 Sevilla, Spain

\section{REFERENCES}

Brito, P.M. 1949. Observações sobre o comportamento da Ema, Rhea americana americana (Linnaeus 1758) en cativeiro. Bol. Mus. Nac. Rio de Janeiro 89: 1-6. 
Brown, J.L. 1987. Helping and Communal Breeding in Birds. Princeton, N.J.: Princeton University Press.

Bruning, D.F. 1973. The Greater Rhea chick and egg delivery route. Nat. Hist. 82: 68-75.

Bruning, D.F. 1974. Social structure and reproductive behavior in the Greater Rhea. Living Bird 13: 251-294.

Codenotti, T.L., Beninca, D. \& Alvarez, F. 1995. Etograma y relación de la conducta con el hábitat y con la edad en el ñandú (Rhea americana). Doñana Acta Vert. 22; 65-86.

Davies, N.B. 1985. Cooperation and conflict among Dunnocks, Prunella modularis, in a variable mating system. Anim. Behav. 33: 628-648.

Fernández, G.F. \& Reboreda, J.C. 1995. Adjacent nesting and egg stealing between males of the Greater Rhea Rhea americana. J. Avian Biol. 26: 321-324.
Handford, P. \& Mares, M.A. 1985. The mating systems of ratites and tinamous: An evolutionary perspective. Biol. J. Linn. Soc. 25: 7-104.

Hudson, W.H. 1927. Los ñandúes de Argentina. Hornero 4: 2-59. Raikow, R.J. 1969. Sexual and agonistic behavior of the Common Rhea. Wilson Bull. 81: 196-206.

Sauer, E.G.F. \& Sauer, E.M. 1966. The behavior and ecology of the South African Ostrich. Living Bird 5: 45-75.

Skutch, A.F. 1987. Helpers at Birds' Nests. Iowa City, Iowa: University of lowa Press.

Stacey, P.B. \& Koenig. W.D. (eds). 1990. Cooperative Breeding in Birds: Long term studies of ecology and behaviour. Cambridge: Cambridge University Press.

Submitted 7 April 1996; revision accepted 10 September 1996 